\title{
Bitter gourd (Momordica charantia) possess developmental toxicity as revealed by screening the seeds and fruit extracts in zebrafish embryos
}

Muhammad Farooq Khan ${ }^{1 *}$ (D, Nael Abutaha ${ }^{1}$, Fahd A. Nasr ${ }^{2}$, Ali S. Alqahtani ${ }^{2}$, Omar M. Noman $^{2}$ and Mohammad A. M. Wadaan'

\begin{abstract}
Background: Bitter gourd (Momordica charantia) has attracted the focus of researchers owing to its excellent anti-diabetic action. The beneficial effect of Momordica charantia on heart has been reported by in vitro and in vivo studies. However the developmental toxicity or potential risk of $M$. charantia on fetus heart development is largely unknown. Hence this study was designed to find out the developmental toxicity of M. charantia using zebrafish (Danio rerio) embryos.

Methods: The crude extracts were prepared from fruit and seeds of M. charantia. The Zebrafish embryos were exposed to serial dilution of each of the crude extract. The biologically active fractions were fractionated by C18 column using high pressure liquid chromatography. Fourier-transform infrared spectroscopy and gas chromatography coupled with mass spectrophotometry was done to identify chemical constituents in fruit and seed extract of $M$. charantia.

Results: The seed extract of $M$. charantia was lethal with $L_{50}$ values of $50 \mu \mathrm{g} / \mathrm{ml}$ to zebrafish embryos and multiple anomalies were observed in zebrafish embryos at sub-lethal concentration. However, the fruit extract was much safe and exposing the zebrafish embryos even to $200 \mu \mathrm{g} / \mathrm{ml}$ did not result any lethality. The fruit extract induced severe cardiac hypertrophy in treated embryos. The time window treatment showed that $M$. charantia perturbed the cardiac myoblast specification process in treated zebrafish embryos. The Fouriertransform infrared spectroscopy analyses revealed diverse chemical group in the active fruit fraction and five new type of compounds were identified in the crude seeds extract of $M$. charantia by gas chromatography and mass spectrophotometry.
\end{abstract}

Conclusion: The teratogenicity of seeds extract and cardiac toxicity by the fruit extract of $M$. charantia warned that the supplementation made from the fruit and seeds of $M$. charantia should be used with much care in pregnant diabetic patients to avoid possible damage to developing fetus.

Keywords: Momordica charantia, Cardiac hypertrophy, Danio rerio, Developmental toxicity

\footnotetext{
* Correspondence: fmuhammad@ksu.edu.sa

${ }^{1}$ Bioproducts Research Chair, College of Science, Department of Zoology,

King Saud University, P.O. Box 2455, Riyadh 11451, Kingdom of Saudi Arabia

Full list of author information is available at the end of the article
}

(c) The Author(s). 2019 Open Access This article is distributed under the terms of the Creative Commons Attribution 4.0 International License (http://creativecommons.org/licenses/by/4.0/) which permits unrestricted use, distribution, and reproduction in any medium, provided you give appropriate credit to the original author(s) and the source, provide a link to the Creative Commons license, and indicate if changes were made. The Creative Commons Public Domain Dedication waiver (http://creativecommons.org/publicdomain/zero/1.0/) applies to the data made available in this article, unless otherwise stated. 


\section{Background}

Herbs have been used in traditional medicine for centuries to cure various ailments, including diabetes mellitus. Bitter gourd is a vegetable widely used in East Asian, South Asian, and Southeast Asian cuisines, and its fruit is generally consumed as a cooked food in its green or early yellowing stage". Moreover, bitter gourd has long been used as an herbal medicine in Asian and African traditional medicines [1-3]. One of the most common uses of $M$. charantia is as an antidiabetic agent. The application of $M$. charantia to treat diabetic mellitus has been extensively studied, which is apparent by the increasing number of publications over the years. PubMed and web of science searches using the key word "Momordica charantia" resulted in 1253 articles for the last 10 years only (20092018). Quite recently, several clinical trials have been conducted to examine the efficacy of $M$. charantia in diabetic patients, and $M$. charantia supplementation was shown to be quite successful in lowering elevated fasting plasma glucose level in prediabetes patients [4-7]. The exact mechanisms of the antidiabetic and anti-obesity effects of $M$. charantia are unknown; however, some of the active components isolated from $M$. charantia are thought to be structurally similar to human insulin [8]. Besides being a potent anti-diabetic supplementation, various parts of $M$. charantia have also been used as a medicine to cure various conditions, such as infection [9-13], wounds [14-16], and osteoarthritis [4, 17]. The plant are also used as laxative, contraceptive, abortifacient, and anthelmintic agents, and also to treat various conditions, such as scabies, jaundice, pneumonia, dysmenorrhea, eczema, gout, leprosy, piles, psoriasis, and rheumatism [18-21]. M. charantia has also been shown to possess strong anticancer properties and strong cytotoxicity in various human cancer cell lines, such as lymphoid leukemia [22], lymphoma, melanoma [23], breast cancer [24], prostatic cancer [25-28], squamous carcinoma of the tongue and larynx. Owing to the promising biological properties and medicinal use of this plant, more than 200 compounds have been isolated and identified from the fruit, leaves, vines, seeds, and roots of $M$. charantia [29, 30].

Cardiomyopathy is one of the most common complications of diabetes mellitus which is believed to be due to the oxidative damage of the heart tissues. The antioxidant property of $M$. charantia has been proven by various studies [31-36]. The beneficial effect of $M$. charantia against the oxidative stress complications in the heart of diabetic rats was demonstrated by [37]. Moreover, the myocardial protective effect from polysaccharides of $M$. charantia has been observed in an isoproterenol (ISP) induced myocardial infarction rat model [38]. M. charantia fruit extract have also showed cardio-protective action in the treatment of diabetic cardiac fibrosis in streptozotocin (STZ) induced diabetes in Sprague-Dawley rats by lowing the expression of type III, type IV collagens and Hydroxyproline content which reverted morphological damages in the heart to normal [39]. However, there is no scientific evidence so far, which can elucidate the action of $M$. charantia on fetal heart development either in animal or in human. The international drug regulatory guidelines emphasize that drugs under development that will be administered to pregnant women must be tested for developmental toxicity in suitable animal models $[40,41]$.

The main objective of this study was to analyze the effect of $M$. charantia on embryonic heart development using zebrafish embryos. Zebrafish (Danio rerio) belongs to the teleost family, and zebrafish embryos are routinely used in developmental toxicology testing as an excellent model organism [42-48]. The main advantage of using zebrafish for such toxicological studies is that, as zebrafish embryo develops outside of mother, thus eliminating the effects of mother on the fetus development and hence toxicity of any compound can easily be assessed directly in the embryos. These mother-related effects are misleading to discover the sensitivity and mechanism of the fetus for developmental abnormalities [49].

Methanol extracts was prepared from the fruit and seeds of $M$. charantia. The crude extracts were further fractionated in trichloromethane, ethyl acetate, methanol, and water. The biologically active fraction (which induced significant level of developmental toxicity in zebrafish embryos) was further fractionated by silica gel column chromatography and high-performance liquid chromatography (HPLC). Phenol and flavonoid contents of the active fraction (ethyl acetate fraction) were determined. The active constituent in seed extract were identified by gas chromatography spectroscopy (GC-MS).

\section{Material and methods Materials}

All reagents used in this study were of HPLC-grade and purchased from Sigma Aldrich.

\section{Methods}

\section{Collection and authentication of plant material}

The fruit and the seeds of bitter gourd (M. charantia) were obtained from commercial local vegetable market and taxonomical identification was confirmed by Dr. Jacob Thomas Pandalayil, Assistant Professor/Curator, Herbarium (King Saud University) in the Department of Botany College of Science, King Saud University, Riyadh, Kingdom of Saudi Arabia. A specimen voucher sample (Acc. No. (KSU) 10626) was deposited in KSU herbarium. 


\section{Plant extraction}

Seedless, fresh fruits $(200 \mathrm{~g})$ of $M$. charantia were cut into small pieces and washed with tap water followed by distilled water. The fruits were air-dried in a ventilated area. After drying, the fruits were grounded using a commercial blender. The dried powder was extracted with methanol using a sonicator at $25^{\circ} \mathrm{C}$ for $30 \mathrm{~min}$ and then kept in a shaking incubator for $24 \mathrm{~h}$ at $250 \mathrm{rpm}$ and $30{ }^{\circ} \mathrm{C}$. The extract was centrifuged at $12000 \mathrm{rpm}$ for 10 min. The solvent was then evaporated using a rotary evaporator at $45^{\circ} \mathrm{C}$, and the extract was weighed and kept at $-80^{\circ} \mathrm{C}$ until use. Crude seed extract was also prepared in a similar manner.

\section{Column chromatography}

M. charantia fruit extract ( $2 \mathrm{~g}$ ) was subjected to column chromatography using silica gel 60 silanized (0.0630.200 mesh; Merck, Darmstadt, Germany). The sample was prepared by adsorbing $2 \mathrm{~g}$ of the extract to $20 \mathrm{~g}$ of silica and then left to dry. The dry powder was applied on top of the column $(5 \times 25 \mathrm{~cm})$ and then eluted using trichloromethane, ethyl acetate, and methanol-water (50:50) with pressure. Each solvent at a volume of $500 \mathrm{ml}$ was collected in a beaker.

\section{$\mathrm{C}_{18}$ cartridge extraction}

$\mathrm{C}_{18}$ cartridges were used to further fractionate the ethyl acetate active fraction isolated from $M$. charantia fruit. The active fraction $(2 \mathrm{~mL})$ was diluted with $8 \mathrm{~mL}$ of distilled water. The SPE cartridge used was Chromabond C18ec-cartridge (Macherey \& Nagel). The cartridge was attached to a vacuum and sequentially conditioned by passing $10 \mathrm{~mL}$ of methanol, $10 \mathrm{~mL}$ of Milli-Q water, and $10 \mathrm{~mL}$ of methanol-water $(2: 8 \mathrm{v} / \mathrm{v})$. Diluted active fraction $(10 \mathrm{~mL})$ was loaded onto the preconditioned cartridge and eluted at a drop-wise to ensure efficient adsorption of the compounds. Elution of $\mathrm{C}_{18}$ cartridgebound compounds was achieved by adding $10 \mathrm{~mL}$ of methanol-water $(2: 8)$, followed by methanol drop-wise. Finally, two fractions were collected and concentrated using a rotary evaporator at $45^{\circ} \mathrm{C}$. The fractions were dried, reconstituted, and stored at $-80^{\circ} \mathrm{C}$ until use.

\section{Phenol estimation}

Total phenolic content of the extracts was measured by the Folin-Ciocalteu method [11]. Briefly, $12.5 \mu \mathrm{L}$ of extract $(1 \mathrm{mg} / \mathrm{mL})$ were mixed thoroughly with $50 \mu \mathrm{L}$ of distilled water and $12.5 \mu \mathrm{L}$ of $25 \%$ Folin-Ciocalteu reagent for $5 \mathrm{~min}$. Next, $125 \mu \mathrm{L}$ of $7 \%(\mathrm{w} / \mathrm{v}) \mathrm{Na}_{2} \mathrm{CO}_{3}$ (sodium carbonate) was added to the mixture, which was then allowed to stand for $1.5 \mathrm{~h}$ at room temperature $\left(25 \pm 2{ }^{\circ} \mathrm{C}\right)$ in the dark. Absorbance was measured at $760 \mathrm{~nm}$ using a microplate reader. Total phenol content was quantified using the standard curve of gallic acid (Joshi et al. 2013).

\section{Flavonoid estimation}

Total flavonoid content in the extracts was quantified according to a method by Ghosh et al. (2008). In brief, $100 \mu \mathrm{L}$ of extract was mixed with $100 \mu \mathrm{L}$ of $2 \%$ aluminum chloride. After $10 \mathrm{~min}$ of incubation, absorbance was measured at $368 \mathrm{~nm}$. The standard curve used to estimate total flavonoids was set using quercetin standard solution (100 to $800 \mathrm{mg} / \mathrm{ml}$ ).

\section{GC/MS analysis}

The gas chromatography-mass spectroscopy (GC-MS) analysis was performed in a Perkin Elmer Clarus 600 gas chromatograph inked to a mass spectrometer essentially same as described previously [50].

\section{Treatment of zebrafish embryos}

The embryos were obtained by natural pairwise breeding. The breeding pairs were set at evening after sunset in 3-1 breeding tanks purchased from Pentair (Pentair Aquatic Eco-Systems, Inc., Apopka, FL, USA). The embryos were collected the following morning by siphoning after the zebrafish spawned at first sunlight. The eggs were washed with distilled water and transferred to embryo water $\left[\mathrm{NaCl} 5.03 \mathrm{mM}, \mathrm{KCl} 0.17 \mathrm{mM}, \mathrm{CaCl} 2 \cdot 2 \mathrm{H}_{2} \mathrm{O}\right.$ $0.33 \mathrm{mM}, \mathrm{MgSO}_{4} \cdot 7 \mathrm{H}_{2} \mathrm{O} 0.33 \mathrm{mM}$, and methylene blue $0.1 \%(\mathrm{w} / \mathrm{v})]$. Synchronized stage embryos at 8 cell stage were exposed to serial dilutions of the extracts in sterile $35-\mathrm{mm}$ glass dishes. Untreated or mock $0.5 \%(\mathrm{v} / \mathrm{v})$ methanol-treated embryos served as controls. The embryos were treated for up to 6 days ( $5 \mathrm{dpf}$ ). The experiment was repeated at least three times by using different batches of embryos each time. The criteria to confirm the teratogenic effect of $M$. charantia in zebrafish embryonic development was when more than $60 \%$ of treated embryos had same effect and also show same $\mathrm{p}$ in all three biological replicates.

After the end of experiment the embryos were euthanized by $0.03 \%$ Tricaine mesylate (Tricaine methanesulfonate, TMS, MS-222, Cat \# E10521,Sigma Aldrich), freeze and discarded as safe biological waste.

\section{Statistics}

Origin (version 6.1052; Origin Lab Corp Northampton, MA, U.S.A.) was used for statistical analysis to calculate the standard deviation between three biological replicates.

\section{Results}

The fruit and seed extracts of Momordica charantia showed different levels of developmental toxicity in zebrafish embryos

To evaluate the developmental toxicity of the fruit and seeds of $M$. charantia, zebrafish embryos were treated with serial dilutions ( 1 to $400 \mu \mathrm{g} / \mathrm{ml}$ ) of crude fruit and seed extracts of $M$. charantia. Zebrafish embryos were 
exposed to the extracts starting from the eight-cell stage of embryonic development up to $5 \mathrm{dpf}$. The mortality or teratogenic effects of the extracts in live embryos were recorded at 24,48 , and $72 \mathrm{~h}$ of post fertilization (hpf).

\section{Lethality}

The crude seed extract of $M$. charantia was more toxic than the crude fruit extract. The dose response of zebrafish embryos exposed to crude extracts is shown in Table 1 . The $\mathrm{LC}_{50}$ value of the $M$. charantia seed extract in zebrafish embryos was $50 \mu \mathrm{g} / \mathrm{ml}$, whereas the fruit extract was found to be harmless, with no significant mortality observed in the zebrafish embryos treated with up to $400 \mu \mathrm{g} / \mathrm{ml}$.

\section{Seed extract of Momordica charantia induced multiple teratological defects in developing zebrafish embryos}

The seed extract of $M$. charantia at sub- $\mathrm{LC}_{50}$ dose interfered with the development and growth of zebrafish embryos. As shown in Fig. 1, the treated embryos showed significant level of developmental arrest, as compared to the mock $(0.5 \%$ methanol $\mathrm{V} / \mathrm{V})$-treated or nontreated zebrafish embryos. As it is evident in Fig. 1 and Table 2, the embryos which were treated with seeds extract exhibited gross abnormalities and development arrest on a dose dependent manner. The zebrafish embryos which were treated with $30 \mu \mathrm{g} / \mathrm{ml}$ of the crude extract $M$. charantia prepared from seeds, showed most severe developmental arrest. The treated embryos did not develop after 15 somite stage (16hpf) whereas, the control embryos had attained the protruding mouth stage $(\sim 72 \mathrm{hpf})$ during the same time period. The embryos which were treated with $20 \mu \mathrm{g} / \mathrm{ml}$ of the seeds extract (Fig. 1c) exhibited enlarged yolk, cardiac hypertrophy with cardiac edema, absence of circulation, absence of tail extensions, and had no pigmentation compared to control embryos. These embryos also failed to hatch. The embryos which were treated with $15 \mu \mathrm{g} / \mathrm{ml}$ crude extract of seeds (Fig. 1d) showed mild level of developmental arrest and but had severe cardiac toxicity. They had cardiac edema and the heart had fused atrium and ventricle resulting a string in the heart and thus

Table 1 Developmental toxicity (lethality) of fruit and seeds extract of $M$. charantia in zebrafish embryos

\begin{tabular}{lll}
\hline $\begin{array}{l}\text { Concentration } \\
\mu \mathrm{g} / \mathrm{ml}\end{array}$ & \multicolumn{2}{c}{ Mortality $^{\mathrm{a}}$} \\
\cline { 2 - 3 } & Fruit extract & Seeds extract \\
\hline 1 & $0.0 \pm 0.00$ & $0.00 \pm 0.0$ \\
5 & $0.0 \pm 0.00$ & $2.0 \pm 0.29$ \\
15 & $0.0 \pm 0.00$ & $25 \pm 0.58$ \\
45 & $0.0 \pm 0.00$ & $40 \pm 0.26$ \\
135 & $3.0 \pm 0.14$ & $100 \pm 0.00$ \\
400 & $10.0 \pm 0.61$ & $100 \pm 0.00$ \\
\hline
\end{tabular}

${ }^{\mathrm{a}}$ Mean of three biological replicates \pm Standard deviation resulting poor circulation. The embryos had curved tail and also absence of tail extension. The embryos which were treated with $10 \mu \mathrm{g} / \mathrm{ml}$ of seeds extract (Fig. 1e and Additional file 2) showed mild developmental arrest. The treated embryos had severe cardiac hypertrophy and cardiac edema. The zebrafish embryos which were treated with $5 \mu \mathrm{g} / \mathrm{ml}$ of the seeds extract (Fig. 1f) showed very mild level of development arrest but exhibited severe cardiac hypertrophy.

\section{GC-MS analysis of phytochemical compounds in Momordica charantia seed extract}

The gas chromatography-mass spectroscopy (GC-MS) analysis was performed to identify the active phytochemical present in the seed extract of $M$. Chrantia. Table 3 and Fig. 2 contain the newly identified phytochemical compounds and details GC-MS analysis from the seed extract of $M$. charantia.

\section{Crude fruit extract of Momordica charantia induced cardiac hypertrophy in treated zebrafish embryos}

The crude fruit extract of $M$. charantia was well tolerated by zebrafish embryos and no mortality was observed even at the highest concentration used $(200 \mu \mathrm{g} / \mathrm{ml})$. The zebrafish embryos treated with the methanol fruit extract showed unaltered embryonic development as the treated embryos were at the same developmental stage as the mock $(0.1 \%$ methanol $\mathrm{v} / \mathrm{v})$-treated counterpart. The cardiac development in control embryos was not affected, and as shown in Fig. 3a and b and Additional file 3, the size of heart was normal with active circulation. However, as evident from Fig. 3c, d, and Table 4 the zebrafish embryos exposed to the crude methanol extract of $M$. charantia developed severe cardiac edema and cardiac hypertrophy. Cardiac hypertrophy was observed in 100\% of embryos $(n=200 \pm 5)$ which were treated with the crude fruit extract at $\geq 30 \mu \mathrm{g} / \mathrm{ml}$. However zebrafish embryos treated with crude fruit extract of $M$. charantia less than $30 \mu \mathrm{g} / \mathrm{ml}$ did not exhibited any noticeable embryonic abnormalities or cardiac toxicity. The measurement of heart size had revealed that the heart of treated embryos were almost double the size as compared to the heart in untreated control embryos (Fig. $3 \mathrm{~b}$ and d). The area of heart was measured microscopically, from five control and five treated embryos at same resolution and at same developmental stage. The mean area of heart from untreated embryos at $72 \mathrm{hpf}$ was $314 \pm 0.70 \mu \mathrm{m}$, whereas the mean area of heart was $504.1 \pm 0.74 \mu \mathrm{m}$ of those embryos which were treated with $200 \mu \mathrm{g} / \mathrm{ml}$ of crude fruit extract of $M$. charantia.

The fruit extract of $M$. charantia also affected the heartbeat rate in treated zebrafish embryos significantly. The control embryos $(n=150)$ had a heartbeat rate of approximately $182 \pm 5$ beats per min (mean heart beat 

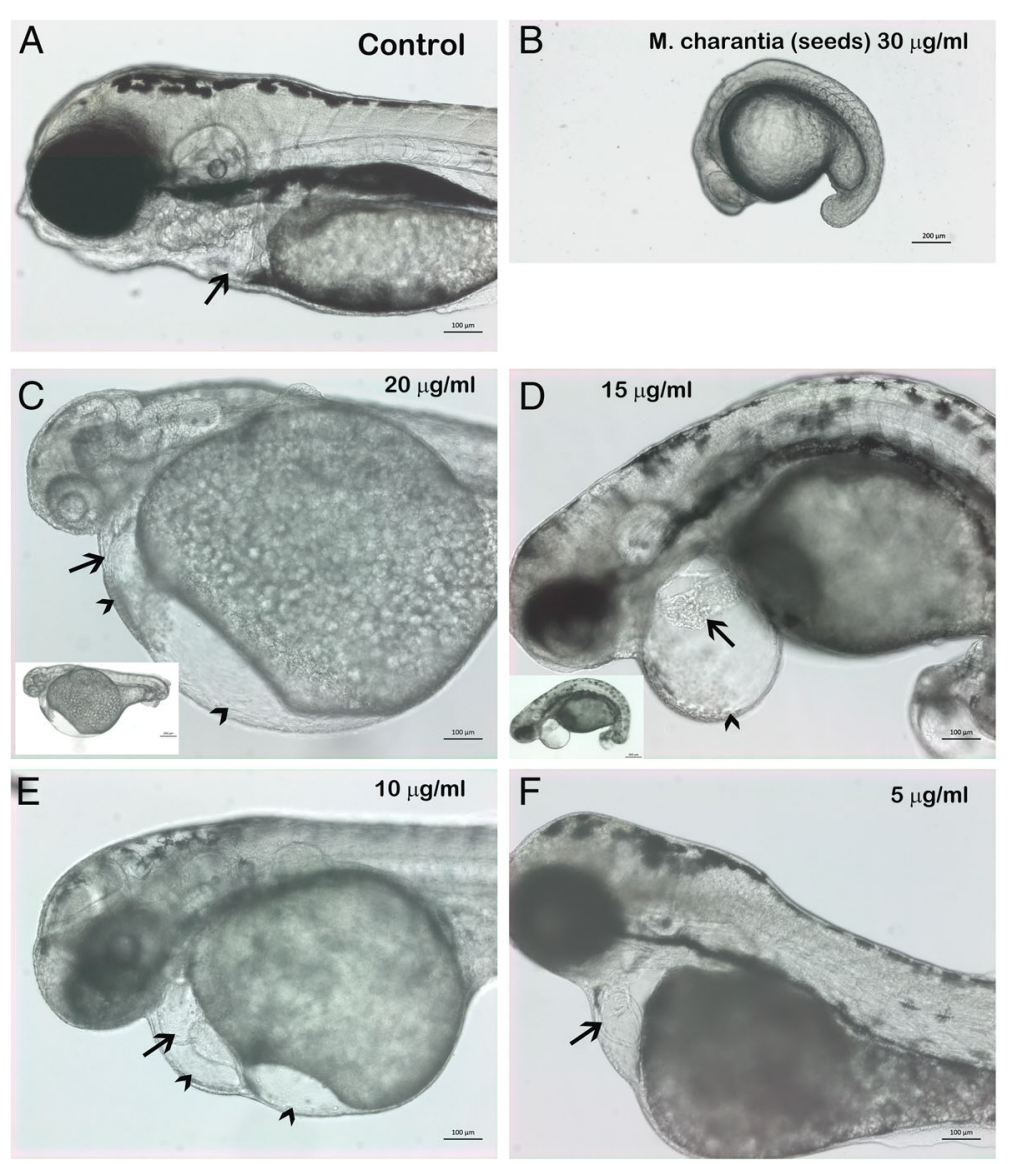

Fig. 1 Seed extract of Momordica charantia induced multiple teratological defects in developing zebrafish embryos. Representative photomicrograph of live zebrafish embryos at $3 \mathrm{dpf}$ control (a) and treated with various concentration of seeds extract of M. charantia (B-F). The highest concentration in which treated embryos could survive was $50 \mu \mathrm{g} / \mathrm{ml}$ and the representative image of treated embryos are presented in $\mathbf{b}$. The embryos treated with $50 \mathrm{\mu g} / \mathrm{ml}$ of seeds extracts were severely developmentally delayed as compared to mock treated embryos as shown in a. The control embryos developed to $72 \mathrm{hpf}$, after two days but treated embryos were at 15 somite stage after two days of exposure. $\mathbf{c}$ The zebrafish embryos which were treated with $25 \mu \mathrm{g} / \mathrm{ml}$ of the seeds extract exhibited multiple teratogenic effect. The treated embryos were developmentally delayed as compared to control, had small head, enlarged yolk (yolk), severe cardiac hypertrophy (arrow), enlarged cardiac cavity (arrow head) absence of tail extension (shown in small inset) absence of circulation (shown in Additional file 1 as supplementary data d). The zebrafish embryos treated with $15 \mu \mathrm{g} / \mathrm{ml}$ of seeds extract of $M$. charantia also had mild level of developmental delay, enlarged cardiac cavity (arrow head). The heart was severely affected as both atrium and ventricle were fused representing as string (black arrow). The treated embryos had curved trunk as shown in small at lower magnification. e. the zebrafish embryos treated with $10 \mu \mathrm{g} / \mathrm{ml}$ of the seeds extract had mild level of developmental delay but the treated embryos ad severe cardiac hypertrophy (arrow) and also enlarged cardiac cavity (arrow head). f). zebrafish embryos treated with $5 \mu \mathrm{g} / \mathrm{ml}$ of the seeds extract did not show development delay however, the cardiac hypertrophy (arrow) was evident in treated embryos. All embryos anterior to the left

rate from five embryos at $72 \mathrm{hpf}$ ), whereas that in $M$. charantia-treated embryos $(\mathrm{n}=150)$ was $\sim 90 \pm 3$ ( $p$ value $0.0005)$ beats per min.

The crude extract prepared from the fruit of $M$. charantia, effected only the heart development process without affecting any other organs in treated zebrafish embryos, which mean that the crude fruit extract have a constituent which caused the cardiac toxicity in zebrafish embryos. In order to identify the cardiac toxicity causing component, the fruit crude extract of $M$. charantia was subjected to column chromatography using silica gel. The yields were $140 \mathrm{mg}$, $80 \mathrm{mg}$, and $1.60 \mathrm{~g}$ for tri- chloromethane, ethyl acetate, and methanol fractions, respectively. The fractions obtained were tested in zebrafish embryos to evaluate their potential toxicity on cardiac development. Among three fractions, only the ethyl acetate fraction induced cardiac hypertrophy in treated zebrafish embryos. This ethyl acetate fraction was further fractionated by HPLC using $C_{18}$ cartridge, which fetched two fractions. The yield of fraction 1 was $36 \mathrm{mg}$ and fraction 2 was $12 \mathrm{mg}$. These two fractions were also screened in zebrafish embryos in order to see which fraction could reproduce the cardiac toxicity phenotype as was observed with crude fruit extract. Fraction 1 did not produce any noticeable toxicity including the cardiac toxicity in 
Table 2 Teratogenic dose response of zebrafish embryos exposed to crude seed extract of $M$. charantia at $72 \mathrm{hpf}$

\begin{tabular}{|c|c|c|c|c|c|c|c|c|}
\hline \multirow{2}{*}{$\begin{array}{l}\text { Concentration } \\
(\mu \mathrm{g} / \mathrm{ml})\end{array}$} & \multicolumn{2}{|c|}{ Developmental arrest ${ }^{a}$} & \multicolumn{2}{|c|}{ Cardiac toxicity $^{a}$} & \multicolumn{2}{|c|}{ Blood circulation $^{a}$} & \multicolumn{2}{|c|}{ Hatching $^{a}$} \\
\hline & Mean & $\pm S . D$ & Mean & $\pm S . D$ & Mean & $\pm S . D$ & Mean & $\pm S . D$ \\
\hline Control & 0 & 0 & 0 & 0 & 0 & 0 & 0 & 0 \\
\hline 1 & 0 & 0 & 0 & 0 & 0 & 0 & 0 & 0 \\
\hline 5 & 0 & 0 & 85 & 0.33 & 85 & 0.33 & 0 & 0 \\
\hline 10 & 0 & 0 & 100 & 0.00 & 100 & 0.00 & 5 & 0.67 \\
\hline 15 & 0 & 0 & 100 & 0 & 100 & 0 & 100 & 0 \\
\hline 20 & 100 & 0 & 100 & 0 & 100 & 0 & 100 & 0 \\
\hline 25 & 100 & 0 & 100 & 0 & 100 & 0 & 100 & 0 \\
\hline 30 & 100 & 0 & 100 & 0 & 100 & 0 & 100 & 0 \\
\hline
\end{tabular}

${ }^{a}$ Percentage of embryos with developmental defect. The values are the mean of three biological replication \pm Standard deviation (S.D)

treated zebrafish embryos, however, fraction \# 2 successfully replicated the cardiac toxicity phenotype in zebrafish embryos and also at much lower concentration i.e. at $10 \mu \mathrm{g} / \mathrm{ml}$ as compared to that of original crude extract (Fig. 3e and $\mathrm{f}$ and Table 4) which indicates that this fraction have higher amount of cardiac toxicity component as compared to crude extract. The heart area measurement revealed that the areas of heart of zebrafish embryos which were exposed to fraction \#2 had severe cardiac hypertrophy and heart areas was not only larger than control embryos but also significantly larger than the heart of embryos which were treated with crude fruit extract of $M$. charantia (Fig. 3e and f).

Fraction 2 was subjected to FTIR spectroscopy in order to identify toxic compound which caused cardiac toxicity in zebrafish embryos. According to the FTIR spectroscopy data; which is shown in Fig. 4, there are peaks occurring at $3315.19 \mathrm{~cm}-1$ could be ascribed to the-OH stretching vibration of hydroxyl groups as well as hydrogen bonding. The band at around $2943.35 \mathrm{~cm}-1$ and $2831.42 \mathrm{~cm}-1$ was assigned to the asymmetric $\mathrm{C}-\mathrm{H}$ stretching vibrations of methylene. The band located at $1022.27 \mathrm{~cm}-1$ was due to $\mathrm{C}-\mathrm{O}$ stretch vibration. The band at around $1449.32 \mathrm{~cm}-1$ and $1413.32 \mathrm{~cm}-1$ was due to the $\mathrm{OH}$ bending vibrations. The band located at $670.60 \mathrm{~cm}-1$ attributed to $\mathrm{O}-\mathrm{H}$ bending vibrations.
The treatment of fruit extract of $M$. charantia perturbed the cardiac specification process during cardiac development in zebrafish embryos

The development or formation of any organ during embryonic development go through two distinct phases. Firs the stem cells are specified to develop into specific cell type and later these cells go through the process of differentiation. Once the cells are differentiated, the size of organ increases by rapid cell division. As it has been shown in this study that the crude fruit extract of $M$. charantia induced cardiac hypertrophy in zebrafish during the embryonic development. Moreover, the effect of crude fruit extract was much localized only heart and it did not disturbed the development of any other organ in zebrafish embryos. So the next question was to find out which process of heart development, (the specification and differentiation of cardiomyocytes or growth and expansion of heart) was altered by $M$. charantia. It could easily be determined if zebrafish embryos are exposed to crude fruit extract by following a time window treatment plan by exposing the zebrafish embryos to crude fruit extract at specified developmental stage of heart development. We planned a time window for exposing zebrafish embryos to the extract at two specific stages of cardiac development: i) before the onset of specification of myocardial progenitor cells (earlier than $5 \mathrm{hpf}$ ), ii) at $48 \mathrm{hpf}$, when heart has

Table 3 Compounds identified in in BG seed methanol extract using GC-MS

\begin{tabular}{|c|c|c|c|c|c|}
\hline Compound Name & Chemical formula & Molecular weight $(\mathrm{g} / \mathrm{mol})$ & $\mathrm{RT}$ (min) & Area & Area\% \\
\hline 1,2-CYCLOPENTANEDIONE & $\mathrm{C}_{5} \mathrm{H}_{6} \mathrm{O}_{2}$ & 98.101 & 6.11 & 3319109 & 59.830 \\
\hline 2,3-DIHYDRO-3,5-DIHYDROXY-6-METHYL-4H-PYRAN-4-ONE & $\mathrm{C}_{6} \mathrm{H}_{8} \mathrm{O}_{4}$ & 144.126 & 8.29 & 1168901 & 21.070 \\
\hline 1,3;2,5-DIMETHYLENE-L-RHAMNITOL & $\mathrm{C}_{8} \mathrm{H}_{14} \mathrm{O}_{5}$ & 190.195 & 11.18 & 639484 & 11.530 \\
\hline ELEMOL & $\mathrm{C}_{15} \mathrm{H}_{26} \mathrm{O}$ & 222.372 & 11.85 & 75925 & 1.370 \\
\hline (-)-SELINA-4.ALPHA.,11-DIOL & $\mathrm{C}_{16} \mathrm{H}_{28}$ & 220.4 & 12.72 & 142414 & 2.570 \\
\hline BETA.-EUDESMOL & $\mathrm{C}_{15} \mathrm{H}_{26} \mathrm{O}$ & 222.372 & 13.82 & 201741 & 3.640 \\
\hline
\end{tabular}




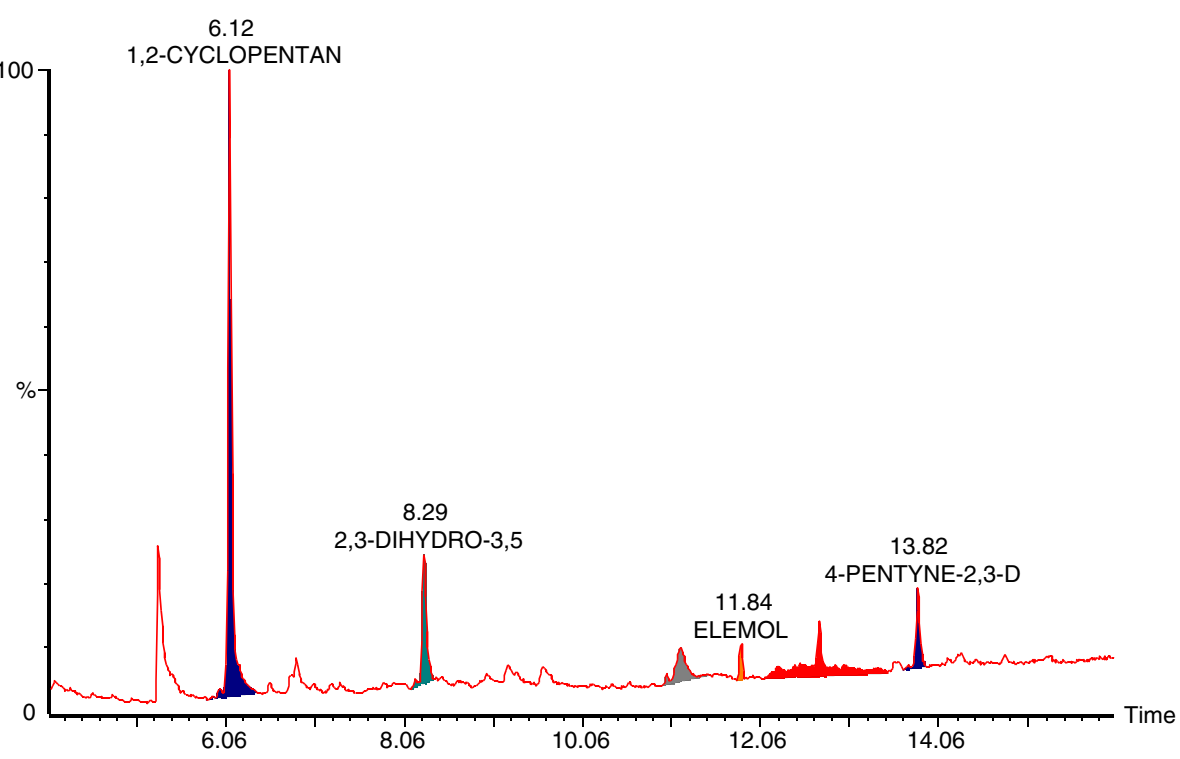

Fig. 2 GC-MS analysis of phytochemical compounds in BG seed methanol extract. The highest peak with least retention time was identified as 1,2- CYCLOPENTANEDIONE which is newly identified compound from the seeds of M.charantia

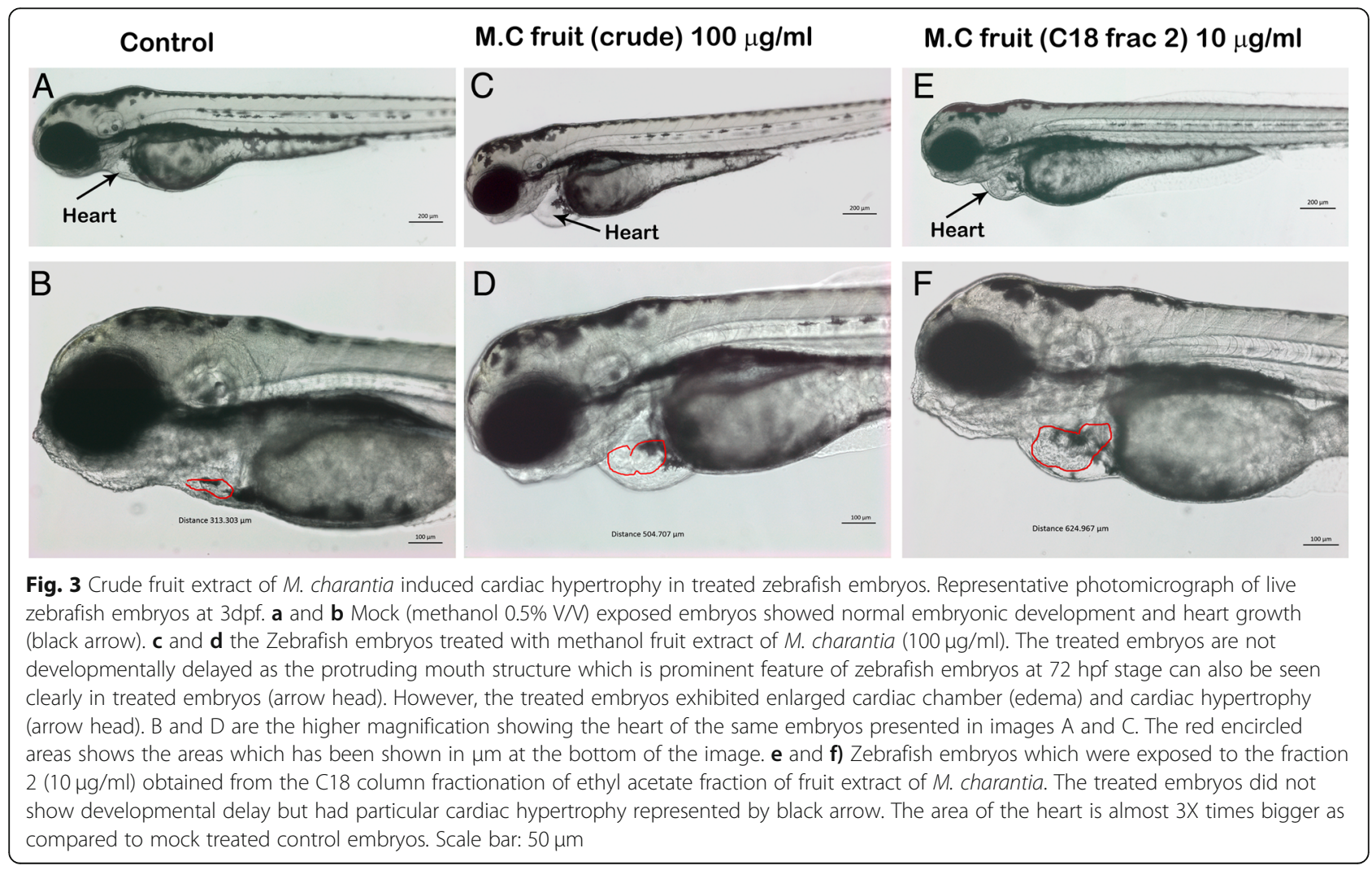


Table 4 Teratogenic dose response of zebrafish embryos exposed to crude and fraction of fruit extract of Momordica charanti at $72 \mathrm{hpf}$

\begin{tabular}{|c|c|c|c|c|c|c|c|c|}
\hline \multirow{2}{*}{$\begin{array}{l}\text { Con. } \\
(\mu \mathrm{g} / \mathrm{ml})\end{array}$} & \multicolumn{2}{|c|}{ Developmental arrest ${ }^{a}$} & \multicolumn{2}{|c|}{ Cardiac toxicity $^{a}$} & \multicolumn{2}{|c|}{ Blood circulation $^{a}$} & \multicolumn{2}{|c|}{ Hatching $^{a}$} \\
\hline & Mean & $\pm S . D$ & $\overline{M e a n}$ & \pm S.D & $\overline{\text { Mean }}$ & \pm S.D & $\overline{\text { Mean }}$ & \pm IS.D \\
\hline \multicolumn{9}{|l|}{ Fruit crude } \\
\hline Control & 0 & 0 & 0 & 0 & 0 & 0 & 0 & 0 \\
\hline 1 & 0 & 0 & 0 & 0 & 0 & 0 & 0 & 0 \\
\hline 5 & 0 & 0 & 0 & 0 & 0 & 0 & 0 & 0 \\
\hline 15 & 0 & 0 & 0 & 0 & 0 & 0 & 0 & 0 \\
\hline 20 & 0 & 0 & 0 & 0 & 0 & 0 & 0 & 0 \\
\hline 25 & 0 & 0 & 0 & 0 & 0 & 0 & 0 & 0 \\
\hline 30 & 0 & 0 & 0 & 0 & 0 & 0 & 0 & 0 \\
\hline 50 & 0 & 0 & 100 & 0 & 100 & 0 & 0 & 0 \\
\hline \multicolumn{9}{|c|}{ Fruit C18 frac. \#2 } \\
\hline Control & 0 & 0 & 0 & 0 & 0 & 0 & 0 & 0 \\
\hline 1 & 0 & 0 & 0 & 0 & 0 & 0 & 0 & 0 \\
\hline 5 & 0 & 0 & 5 & 0.25 & 0 & 0 & 0 & 0 \\
\hline 10 & 0 & 0 & 100 & 0 & 100 & 0 & 0 & 0 \\
\hline 15 & 0 & 0 & 100 & 0 & 100 & 0 & 0 & 0 \\
\hline
\end{tabular}

${ }^{a}$ Percentage of embryos showing the developmental defect. The values are the mean of three biological replication \pm Standard deviation (S.D)

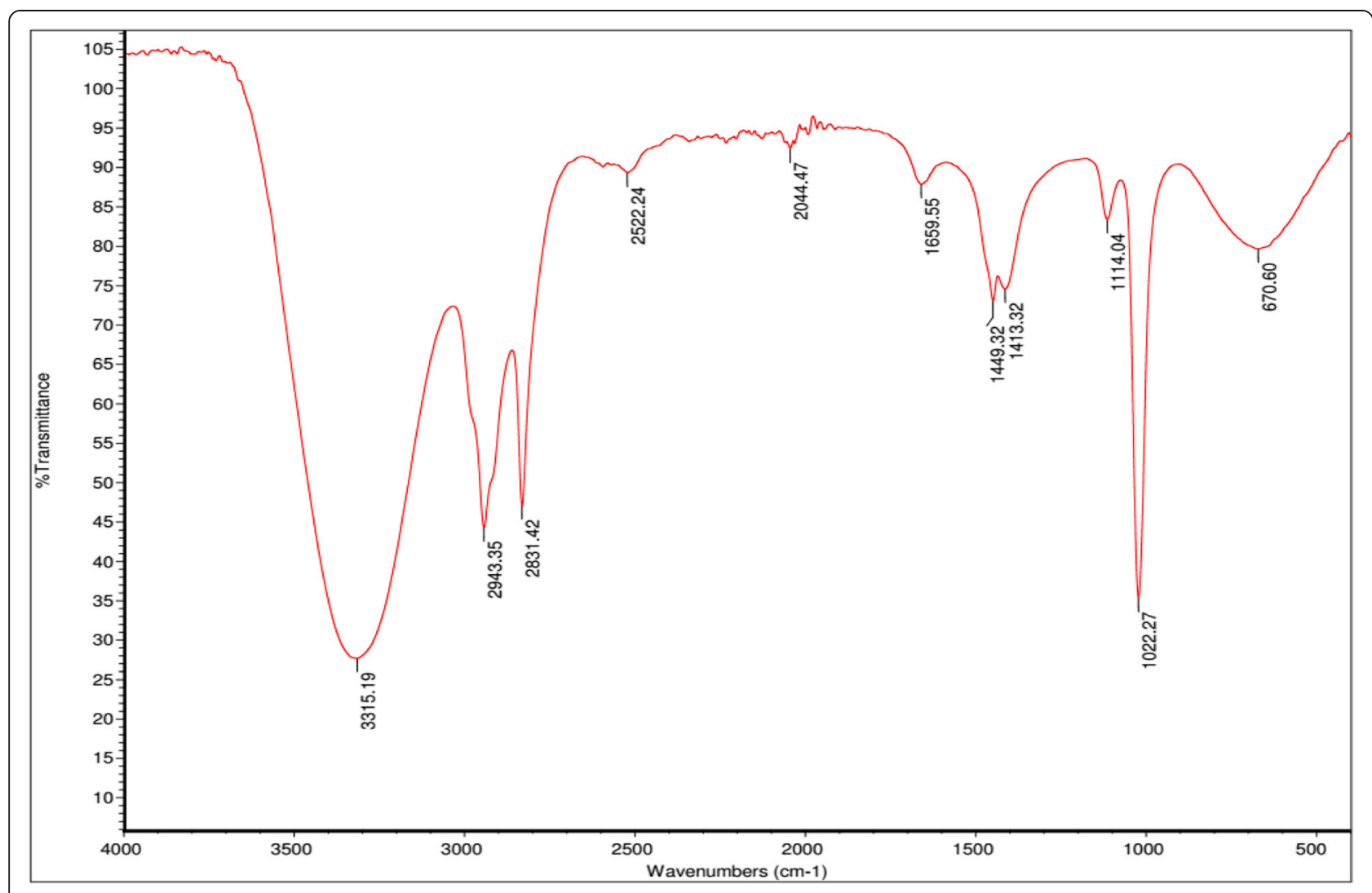

Fig. 4 IR fingerprint of the rich-phenolic extract isolated from ethyl acetate fraction of $M$. charantia fruit extract 
totally formed and become a functional organ. As shown in the Fig. 5a, e and f, the crude fruit extract was only active when it was added before the time of cardiac cell specification and differentiation. The cardiac hypertrophy was only observed in those zebrafish embryos which were treated with $M$. charantia before 5 hpf (cardiac cell specification stage) and exposure to $M$. charantia after this window, i.e. after $48 \mathrm{hpf}$, did not result in cardiac hypertrophy or any kind of observable malformation in zebrafish embryos.

In order to find out the synergic effect or combined toxicity of seeds and fruit of $M$. charantia on zebrafish embryonic development, the zebrafish embryos were exposed to both extract at the same time. A combined dose of $50 \mu \mathrm{g} / \mathrm{ml}$ each of crude fruit and crude seeds extract, resulted $100 \%$ of lethality of embryos just after 24 $\mathrm{h}$ post treatment. Similarly, the combined doses in which crude seed extract was used at concentration of $30 \mu \mathrm{g} /$ $\mathrm{ml}$ and crude fruit extract was used at concentration of $50 \mu \mathrm{g} / \mathrm{ml}$ also resulted $100 \%$ death of treated embryos. The combined dose monitoring of two extracts had shown that, the survival of embryos was only possible when the amount of crude seed extract was kept $\leq 5 \mu \mathrm{g} /$ $\mathrm{ml}$. As shown in Fig. 6, the embryos which were treated with $5 \mu \mathrm{g} / \mathrm{ml}$ of seeds extract and $30 \mu \mathrm{g} / \mathrm{ml}$ of fruit extract had survived up to $96 \mathrm{hpf}$ but exhibited severe cardiac malformation showing fusing of ventricle and atrium as string and had nonfunctional heart (no contraction and circulation).

\section{Discussion}

The most common medicinal use of $M$. charantia is as an effective treatment of diabetes. Number of studies have been conducted to determine the safety profile of $M$. charantia in experimental animals; and all have found that $M$. charantia did not show any kind of toxicity when tested in non-pregnant animals $[8,51-56]$.

The safety profile of $M$. charantia is largely unknown in pregnant women so far, and consumption of $M$. charantia as an antidiabetic remedy by pregnant women cannot be overruled. Moreover, $M$. charantia has never been extensively studied in pregnant animals to elucidate the potential risk of $M$. charantia on fetus development. We have found only one report in the literature describing the teratological profile of $M$. charantia in pregnant experimental animals. Multiple congenital litter malformations were observed following exposure of pregnant Sprague Dawley rats to a water extract of fruit of $M$. charantia [57]. Guidelines by the Food and Drug Administration (FDA) clearly indicate that new developing drug that are
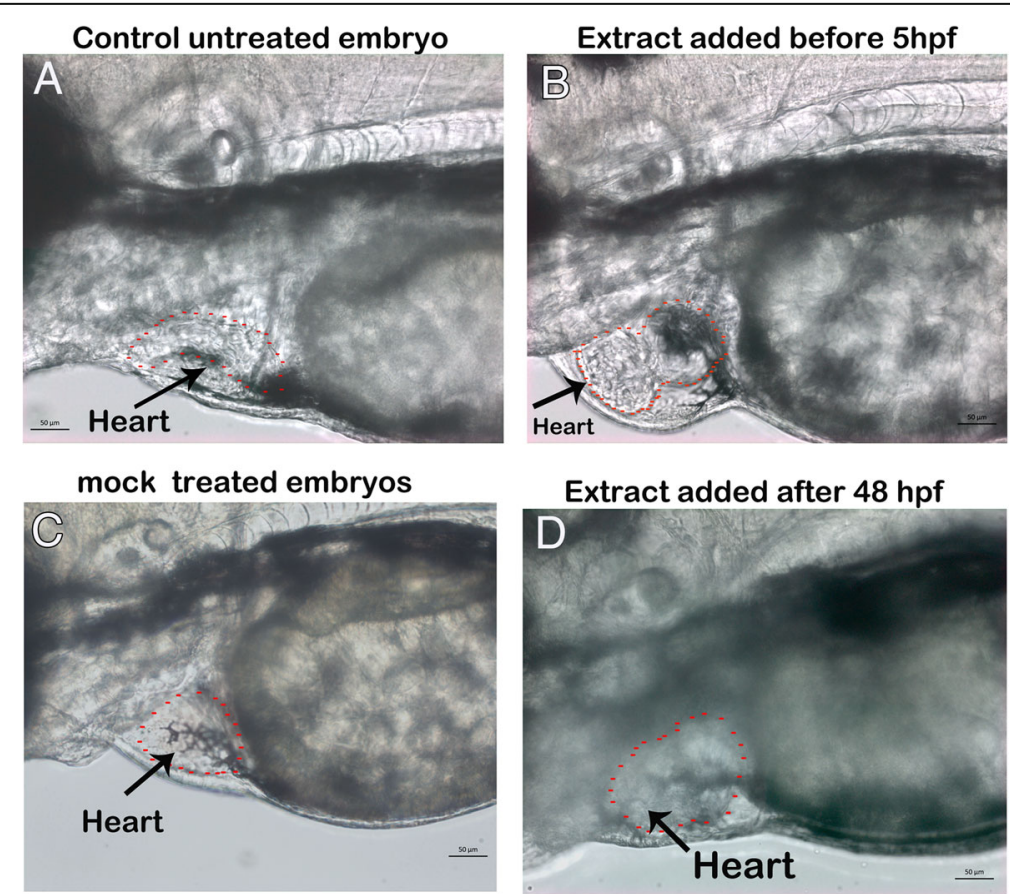

\section{Extract added after $48 \mathrm{hpf}$}

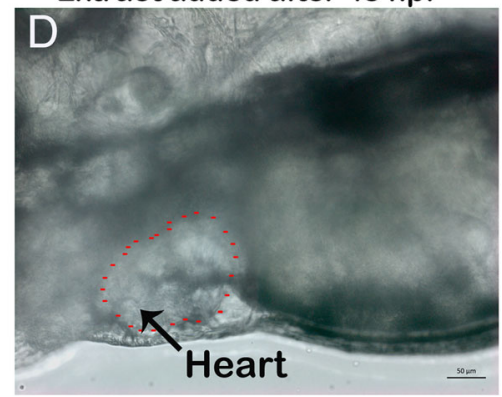

Fig. 5 The fruit extract of M .Charantia effected the heart formation not the heart growth in treated zebrafish embryos. Representative live photomicrograph of zebrafish embryos at $72 \mathrm{hpf}$. a: Untreated control embryos at $72 \mathrm{hpf}$ showing the normal formation and development of heart (red dots area represented by arrow). b: Zebrafish embryos which were treated with fruit extract of $M$. charantia at one cells stage exhibited the cardiac hypertrophy (red dots area and black arrow). c: The mock (methanol $0.5 \% \mathrm{v} / \mathrm{v}$ ) treated embryos which were treated with solvent at one cell stage had normally heart development. d: Zebrafish embryos which were exposed to fruit extract of $M$. charantia at 48 hpf also had normal heart formation and development (red dot area). Abbreviation hpf: hours post fertilization. Scale bar $50 \mu m$ 

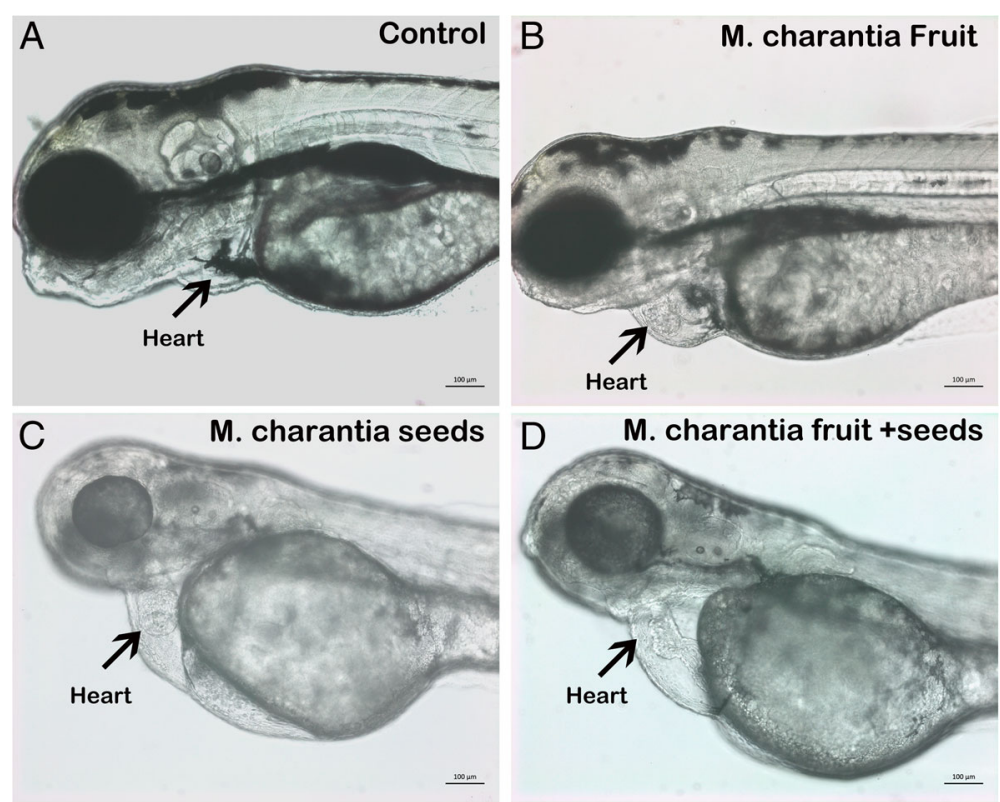

Fig. 6 The co exposure of fruit and seeds extracts of M. charantia resulted lethality and severe cardiac toxicity in zebrafish embryos. Representative photomicrograph showing live zebrafish embryos at $3 \mathrm{dpf}$ control or treated with fruit, seeds or combination of seeds and fruit extract of M. charantia. a The mock (methanol 0.5\% VN) exposed embryos did develop normally and had normal heart growth and development. b The zebrafish embryos treated with fruit extract $(100 \mu \mathrm{g} / \mathrm{ml})$ had severe cardiac hypertrophy, c the embryos treated with $15 \mu \mathrm{g} / \mathrm{ml}$ of seeds extract had cardiac hypertrophy and also enlarged cardiac cavity. $\mathbf{d}$ The embryos which were treated with combination of both extract showed severe effect on heart formation as fused ventricle and atrium represented as string and also enlarged heart cavity

intended for use in pregnant women must first be tested in suitable pregnant animal models [58].

The fruit and seeds of $M$. charantia, both are being used in anti-diabetic remedies $[59,60]$, however, the toxicity profile of fruit part in animal models systems has been investigated in previous reports but we did not find any published literature prior to this study, describing any toxicity profile of seeds of $M$. charantia. Various mammalian systems are traditionally used to examine the developmental toxicity of chemicals. The traditional methods are lengthy, costly, and often require a large number of animals, which raises ethical concerns. Moreover, testing any compound isolated from natural sources would be impractical owing to the limitation of quantity, because a large quantity of test material is normally needed for such screening methods. Zebrafish has emerged as a cost-effective and useful model for in vivo toxicity testing, and it is being routinely used for assessing the developmental toxicity of drugs or chemicals $[43,61]$. Zebrafish embryos are very small in size; thus, by using this animal, it is possible to conduct a highthroughput screening in 90-well cell culture plates using very small quantity of test materials. Furthermore, a large number of embryos can be used for statistical application without ethical concerns because zebrafish embryo and larvae up to $5 \mathrm{dpf}$ are exempted from requirement of approval by an ethical committee for animal use and care (Bartlett \& Silk, 2016; Strahle et al., 2012).

The development process of zebrafish is largely comparable to that of mammalians [47, 62, 63], and this model is even used as a model for studying type 2 diabetes mellitus [64].

Treatment with crude seed extract of $M$. charantia to zebrafish embryos resulted in severely malformed embryos. The treated embryos were severely developmentally delayed than their non-treated counterparts, thus the seed extract or any supplementation prepared from the seed of $M$. charantia must be used with utmost care in pregnant women owing to the possible risk of fetus malformation, based on the result of this study.

The fruit part of M.charantia has been extensively studied and also lot of phytochemical has been identified from fruit part. The chemical constituents which have been identified from the fruit part of $M$. charantia has been best reviewed by [18]. The phytochemical from the seeds of $M$. charantia is largely unknown, hence only seeds extract was subjected to GC-MS analysis in this study. The GC-MS analysis helped to identify six new phytochemicals from the seeds of $M$. charantia. 1,2-CYCLOPENTANEDIONE has been identified with major peak which covered almost $60 \%$ of the areas. The molecular weight of, 2-CYCLOPENTANEDIONE estimated to be 98.11. The biological activity of 1,2-CYCLOPENTANEDIONE is 
largely unknown but a similar compound 3-methyl-1,2cyclopentanedione has been shown to be peroxisome proliferator-activated receptor $\gamma(\mathrm{PPAR} \gamma)$ agonist [65]. Interestingly peroxisome proliferator-activated receptor $\gamma$ (PPAR $\gamma$ ) agonist are insulin sensitizers and widely used in the treatment of type 2 diabetes and cardiac hypertrophy has been reported in few preclinical studies using such agonists [66]. Whether 1,2-CYCLOPENTANEDIONE is PPAR $\gamma$ agonist or not need to be investigated experimentally, however, the cardiac hypertrophy in zebrafish embryos by seeds extract of $M$. charantia mimics the PPARY agonist phenotype, which means 1,2-CYCLOPENTANEDIONE could be PPARY agonist as well and hence 1,2-CYCLOPENTANEDIONE which has been identified as a major compound in seeds extract could be causing agent for cardiac hypertrophy in zebrafish embryos.

Treatment with the crude extract of unripe fruits of $M$. charantia did not induce sever level of malformation in zebrafish embryos in this study. The treated embryos were synchronous in development, as compared to the untreated control embryos. However, $100 \%$ of the treated zebrafish embryos developed cardiac hypertrophy, which was evident from $24 \mathrm{hpf}$ onward. Severity of cardiac hypertrophy was directly correlated to the concentration of extract. The treated embryos developed cardiac hypertrophy after treatment with $\leq 25 \mu \mathrm{g} / \mathrm{ml}$ of fruit crude extract, whereas heart malformation was only evident in the zebrafish embryos treated with $\geq 30 \mu \mathrm{g} / \mathrm{ml}$ of fruit extract. The heart is the first organ to form and function during embryonic development in zebrafish, as in other vertebrates as well. Cardiac development in vertebrates usually begins with the specification of myocardial and endocardial progenitor cells, and cell-labeling techniques have helped visualizing the first myocardial progenitor cells in developing zebrafish embryos at approximately 5 hpf (before gastrulation starts) $[67,68]$. The cardiovascular system of zebrafish is a closed system, as in other vertebrates, and the physiology of its cardiac cycle is highly representative of that of humans [69].

A specific time window treatment was planned to treat the embryos at different stages of cardiac development in order to elucidate either cardiac development or cardiac growth has been compromised by $M$. charantia.. Cardiac development monitoring during zebrafish embryonic development by various labeling and imaging techniques has revealed that the first myocardial progenitor cells undergo specification at approximately $5 \mathrm{hpf}$ (before gastrulation starts) in developing zebrafish embryos. Myocardial cells start differentiation at the 12-somite stage (15 hpf). Cardiac looping takes place between 36 and $48 \mathrm{hpf}$, and functional heart, which has completed the cardiac development process, occurs at approximately $48 \mathrm{hpf}[67,68]$. The cardiac hypertrophy was only apparent in treated zebrafish embryos when they were exposed to the crude extract of
M. charantia, between one-cell and $5 \mathrm{hpf}$, that is before the onset of cardiac cell specification, and cardiac toxicity was not observed in those embryos which were treated with the same extract at same concentration at or after $48 \mathrm{hpf}$ (after the cardiac development process had completed) and also did not show any obvious embryonic malformations. The exact mechanism and underlying molecular pathway which have been affected by $M$. charantia resulting the cardiac toxicity in zebrafish embryos is not known but the result from this study clearly indicates that the crude fruit extract of $M$. charantia affected the specification of myocardial cells and possibly by blocking those biological process and transcription factors which are normally required for the specification of myoblast. The cardiac toxicity of bitter gourd has also been reported in at least one another study. [58] Observed a significant increase in the cardiac weights of newly born litters of pregnant Sprague Dawley females rats which were treated with water fruit extract of $M$. charantia as compared to non-treated control group. The cardiac hypertrophy as observed in treated zebrafish embryos in this study confirmed the findings of [58] and hence the use of bitter gourd supplementation as anti-diabetic remedy in pregnant women must be use with extreme cautions to avoid any possible toxicity to developing fetus. The cardiac toxicity of $M$. charantia in adult animals or human is unknown; however, a clinical case of mild atrial fibrillation has been reported in one patient who consumed large amount of $M$. charantia juice [70].

\section{Conclusion}

Herbs, as well as medicine or compounds derived from natural sources, have been generally anticipated to be free from toxicities and side effects, and the same was thought to be true for $M$. charantia. Cardiac toxicity induced by $M$. charantia fruit extract and gross teratological effects induced by $M$. charantia seed extract in zebrafish embryos in this study, as well as the results of the toxicity study in pregnant rats in a previous study, clearly warned that bitter gourd should be used with caution by pregnant women and that pharmacological studies should be conducted to determine the safe dose and duration of treatment with $M$. charantia in pregnant women.

\section{Additional files}

Additional file 1: BG heart compressedR3. (MP4 2803 kb)

Additional file 2: BG seeds heartR3. (MP4 $6156 \mathrm{~kb}$ )

Additional file 3: controlR3. (MP4 $6156 \mathrm{~kb}$ )

\section{Abbreviations}

DPF: Days post fertilization; FTIR: Fourier-transform infrared spectroscopy; HPF: Hours post fertilization; HPLC: High-performance liquid chromatography; IACUC: An Institutional Animal Care and Use Committee; $M$.

charantia: Momordica charantia 


\section{Acknowledgements}

The authors are grateful to the Deanship of Scientific Research at King Saud University for funding this study through Vice-Deanship of "Scientific Research Chairs". The authors also thank the Research support unit (RSSU) at Deanship of Scientific Research, King Saud University for their technical support.

\section{Consent to participate}

Not applicable.

\section{Authors' contributions}

MF and NT conceived and designed the study, carried out extraction, characterization and chemical composition analysis of the fruit extract. MF carried out the zebrafish screening assays. FN, AQ, and ON carried out GCMS analysis of the seeds extract and MA supervised the research. All authors read and approved the final manuscript.

\section{Funding}

This study was funded by Deanship of Scientific Research, King Saud University through Vice Deanship of Scientific Research Chairs. The funding body have NO role in the design of the study and collection, analysis, and interpretation of data and in writing the manuscript.

\section{Availability of data and materials}

The raw data used and/or analyzed during the current study will be available from the corresponding author on reasonable request.

\section{Ethics approval and consent to participate}

Wild-type zebrafish were obtained from the Zebrafish International Resource Center, University of Oregon, Eugene, OR, USA, and maintained according to the standard IACUC guidelines for the use and care of laboratory animals and zebrafish book [71]. This study used zebrafish embryos aged less than 6 $\mathrm{dpf}$, thus requiring no approval from the institutional animal use committee as stated by new IACUC guidelines for the use and care of laboratory animals $[72,73]$

\section{Consent for publication}

Not applicable.

\section{Competing interests}

The authors declare that they have no competing interests.

\section{Author details}

${ }^{1}$ Bioproducts Research Chair, College of Science, Department of Zoology, King Saud University, P.O. Box 2455, Riyadh 11451, Kingdom of Saudi Arabia. ${ }^{2}$ Medicinal Aromatic, and Poisonous Plants Research Center, College of Pharmacy, King Saud University, Riyadh 11451, Saudi Arabia.

\section{Received: 22 May 2019 Accepted: 16 July 2019}

Published online: 24 July 2019

\section{References}

1. Grover JK, Yadav SP. Pharmacological actions and potential uses of Momordica charantia: a review. J Ethnopharmacol. 2004;93(1):123-32.

2. Beloin N, Gbeassor M, Akpagana K, Hudson J, de Soussa K, Koumaglo K, Arnason JT. Ethnomedicinal uses of Momordicacharantia (Cucurbitaceae) in Togo and relation to its phytochemistry and biological activity. J Ethnopharmacol. 2005:96(1-2):49-55.

3. Saxena A, Vikram NK. Role of selected Indian plants in management of type 2 diabetes: a review. J Altern Complement Med. 2004;10(2):369-78.

4. Soo May L, Sanip Z, Ahmed Shokri A, Abdul Kadir A, Md Lazin MR. The effects of Momordica charantia (bitter melon) supplementation in patients with primary knee osteoarthritis: a single-blinded, randomized controlled trial. Complement Ther Clin Pract. 2018;32:181-6.

5. Cortez-Navarrete M, Martinez-Abundis E, Perez-Rubio KG, Gonzalez-Ortiz M, Mendez-Del Villar M. Momordica charantia administration improves insulin secretion in type 2 diabetes mellitus. J Med Food. 2018;21(7):672-7.

6. Krawinkel MB, Ludwig C, Swai ME, Yang RY, Chun KP, Habicht SD. Bitter gourd reduces elevated fasting plasma glucose levels in an intervention study among prediabetics in Tanzania. J Ethnopharmacol. 2018;216:1-7.
7. Inayat UR, Khan RU, Khalil Ur R, Bashir M. Lower hypoglycemic but higher antiatherogenic effects of bitter melon than glibenclamide in type 2 diabetic patients. Nutr J. 2015;14:13.

8. Basch E, Gabardi S, Ulbricht C. Bitter melon (Momordica charantia): a review of efficacy and safety. Am J Health-Syst Ph. 2003;60(4):356-9.

9. Chen JC, Liu WQ, Lu L, Qiu MH, Zheng YT, Yang LM, Zhang XM, Zhou L, Li ZR. Kuguacins F-S, cucurbitane triterpenoids from Momordica charantia. Phytochemistry. 2009;70(1):133-40.

10. Sonibare MA, Moody JO, Adesanya EO. Use of medicinal plants for the treatment of measles in Nigeria. J Ethnopharmacol. 2009:122(2):268-72.

11. Chunthorng-Orn J, Panthong S, Itharat A. Antimicrobial, antioxidant activities and total phenolic content of Thai medicinal plants used to treat HIV patients. J Med Assoc Thai. 2012:95(Suppl 1):S154-8.

12. Poolperm $S$, Jiraungkoorskul W. An update review on the anthelmintic activity of bitter gourd, Momordica charantia. Pharmacogn Rev. 2017; 11(21):31-4

13. Chao CY, Sung PJ, Wang WH, Kuo YH. Anti-inflammatory effect of Momordica charantia in sepsis mice. Molecules. 2014;19(8):12777-88.

14. Jha DK, Koneri R, Samaddar S. Medicinal use of an ancient herb Momordica Cymbalaria: a review. Int J Pharm Sci Res. 2018;9(2):432-41.

15. Hussan F, Yahaya MF, Teoh SL, Das S. Herbs for effective treatment of diabetes mellitus wounds: medicinal chemistry and future therapeutic options. Mini-Rev Med Chem. 2018;18(8):697-710.

16. Alippilakkotte $S$, Kumar S, Sreejith L. Fabrication of PLA/ag nanofibers by green synthesis method using Momordica charantia fruit extract for wound dressing applications. Colloid Surface A. 2017;529:771-82.

17. Abu Bakar Fl, Abu Bakar MF, Rahmat A, Abdullah N, Sabran SF, Endrini S. Anti-gout potential of Malaysian medicinal plants. Front Pharmacol. 2018;9:261.

18. Jia S, Shen MY, Zhang F, Xie JH. Recent advances in Momordica charantia: functional components and biological activities. Int J Mol Sci. 2017;18(12). Int J Mol Sci. 2017:18:2555. https://doi.org/10.3390/ijms1812255.

19. Wang SZ, Li ZL, Yang GL, Ho CT, Li SM. Momordica charantia: a popular health-promoting vegetable with multifunctionality. Food Funct. 2017:8(5): 1749-62.

20. Rashid MMO, Ferdous J, Banik S, Islam MR, Uddin AHMM, Robel FN. Anthelmintic activity of silver-extract nanoparticles synthesized from the combination of silver nanoparticles and M. charantia fruit extract. BMC Complem Altern M. 2016;16:242.

21. Upadhyay A, Agrahari P, Singh DK. A review on salient pharmacological features of Momordica charantia. Int J Pharmacol. 2015;11(5):405-13.

22. Licastro F, Franceschi C, Barbieri L, Stirpe F. Toxicity of Momordica charantia lectin and inhibitor for human normal and leukaemic lymphocytes. Virchows Arch B Cell Pathol Incl Mol Pathol. 1980;33(3):257-65.

23. da Silva TB, Costa CO, Galvao AF, Bomfim LM, Rodriques AC, Mota MC, Dantas AA, Dos Santos TR, Soares MB, Bezerra DP. Cytotoxic potential of selected medicinal plants in Northeast Brazil. BMC Complement Altern Med. 2016:16:199.

24. Bai LY, Chiu CF, Chu PC, Lin WY, Chiu SJ, Weng JR. A triterpenoid from wild bitter gourd inhibits breast cancer cells. Sci Rep. 2016;6:22419.

25. Pitchakarn P, Suzuki S, Ogawa K, Pompimon W, Takahashi S, Asamoto M, Limtrakul P, Shirai T. Kuguacin J, a triterpeniod from Momordica charantia leaf, modulates the progression of androgen-independent human prostate cancer cell line, PC3. Food Chem Toxicol. 2012:50(3-4):840-7.

26. Ru P, Steele R, Nerurkar PV, Phillips N, Ray RB. Bitter melon extract impairs prostate cancer cell-cycle progression and delays prostatic intraepithelial neoplasia in TRAMP model. Cancer Prev Res (Phila). 2011;4(12):2122-30.

27. Pitchakarn P, Suzuki S, Ogawa K, Pompimon W, Takahashi S, Asamoto M, Limtrakul P, Shirai T. Induction of G1 arrest and apoptosis in androgendependent human prostate cancer by Kuguacin J, a triterpenoid from Momordica charantia leaf. Cancer Lett. 2011;306(2):142-50.

28. Pitchakarn P, Ogawa K, Suzuki S, Takahashi S, Asamoto M, Chewonarin T, Limtrakul P, Shirai T. Momordica charantia leaf extract suppresses rat prostate cancer progression in vitro and in vivo. Cancer Sci. 2010;101 (10):2234-40.

29. Singh J, Cumming E, Manoharan G, Kalasz H, Adeghate E. Medicinal chemistry of the anti-diabetic effects of momordica charantia: active constituents and modes of actions. Open Med Chem J. 2011;5(Suppl 2):70-7.

30. Raman A, Lau C. Anti-diabetic properties and phytochemistry of Momordica charantia L. (Cucurbitaceae). Phytomedicine. 1996;2(4):349-62.

31. Wang L, Clardy A, Hui DF, Gao AW, Wu Y. Antioxidant and antidiabetic properties of Chinese and Indian bitter melons (Momordica charantia L.). Food Biosci. 2019;29:73-80 
32. Njume C, Donkor O, McAinch AJ. Predisposing factors of type 2 diabetes mellitus and the potential protective role of native plants with functiona properties. J Funct Foods. 2019;53:115-24.

33. Wan-Nadilah WA, Khozirah S, Khatib A, Hamid AA, Hamid M. Evaluation of the alpha-glucosidase inhibitory and free radical scavenging activities of selected traditional medicine plant species used in treating diabetes. Int Food Res J. 2019;26(1):75-85

34. Maneenin C, Burawat J, Maneenin N, Nualkaew S, Arun S, Sampannang A, lamsaard S. Antioxidant capacity of Momordica charantia extract and its protective effect on testicular damage in Valproic acid-induced rats. Int J Morphol. 2018:36(2):447-53.

35. Sandikapura MJ, Nyamathulla S, Noordin MI. Comparative antioxidant and antidiabetic effects of Syzygium polyanthum leaf and Momordica charantia fruit extracts. Pak J Pharm Sci. 2018;31(2):623-35.

36. Torkamani AE, Syahariza ZA, Norziah MH, Wan AKM, Juliano P. Encapsulation of polyphenolic antioxidants obtained from Momordica charantia fruit within zein/gelatin shell core fibers via coaxial electrospinning. Food Biosci. 2018;21:60-71

37. Tripathi UN, Chandra D. The plant extracts of Momordica charantia and Trigonella foenum graecum have antioxidant and anti-hyperglycemic properties for cardiac tissue during diabetes mellitus. Oxidative Med Cell Longev. 2009;2(5):290-6.

38. Raish M. Momordica charantia polysaccharides ameliorate oxidative stress, hyperlipidemia, inflammation, and apoptosis during myocardial infarction by inhibiting the NF-kappaB signaling pathway. Int J Biol Macromol. 2017;97:544-51.

39. Abas R, Othman F, Thent ZC. Protective effect of Momordica charantia fruit extract on hyperglycaemia-induced cardiac fibrosis. Oxidative Med Cell Longev. 2014;2014:429060.

40. Barrow P. Revision of the $\mathrm{ICH}$ guideline on detection of toxicity to reproduction for medicinal products: SWOT analysis. Reprod Toxicol. 2016;64:57-63.

41. Bass R, Ulbrich B, Hildebrandt AG, Weissinger J, Doi O, Baeder C, Fumero S, Harada $Y$, Lehmann $H$, Manson J, et al. Draft guideline on detection of toxicity to reproduction for medicinal products. Adverse Drug React T. 1991; 10(3):127-41.

42. Pina B, Navarro L, Barata C, Raldua D, Martinez R, Casado M. Omics in zebrafish Teratogenesis. Methods Mol Biol. 2018;1797:421-41.

43. Nishimura Y, Inoue A, Sasagawa S, Koiwa J, Kawaguchi K, Kawase R, Maruyama T, Kim S, Tanaka T. Using zebrafish in systems toxicology for developmental toxicity testing. Congenit Anom. 2016;56(1):18-27.

44. Kanungo J, Cuevas E, Ali SF, Paule MG. Zebrafish model in drug safety assessment. Curr Pharm Des. 2014:20(34):5416-29.

45. Gibert $Y$, Trengove MC, Ward AC. Zebrafish as a genetic model in preclinical drug testing and screening. Curr Med Chem. 2013;20(19):2458-66.

46. Teraoka H, Dong W, Hiraga T. Zebrafish as a novel experimental model for developmental toxicology. Congenit Anom. 2003;43(2):123-32.

47. Nishimura Y, Murakami S, Ashikawa Y, Sasagawa S, Umemoto N, Shimada Y, Tanaka T. Zebrafish as a systems toxicology model for developmental neurotoxicity testing. Congenit Anom. 2015;55(1):1-16.

48. Ota S, Kawahara A. Zebrafish: a model vertebrate suitable for the analysis of human genetic disorders. Congenit Anom. 2014;54(1):8-11.

49. Arenzana FJ, Carvan MJ 3rd, Aijon J, Sanchez-Gonzalez R, Arevalo R, Porteros A. Teratogenic effects of ethanol exposure on zebrafish visual system development. Neurotoxicol Teratol. 2006:28(3):342-8.

50. Hidayathulla S, Shahat AA, Ahamad SR, Al Moqbil AAN, Alsaid MS, Divakar DD. GC/MS analysis and characterization of 2-Hexadecen-1-ol and beta sitosterol from Schimpera arabica extract for its bioactive potential as antioxidant and antimicrobial. J Appl Microbiol. 2018;124(5):1082-91.

51. Shanker K, Naradala J, Mohan GK, Kumar GS, Pravallika PL. A sub-acute oral toxicity analysis and comparative in vivo anti-diabetic activity of zinc oxide, cerium oxide, silver nanoparticles, and Momordica charantia in streptozotocin-induced diabetic Wistar rats. RSC Adv. 2017;7(59):37158-67.

52. Deshmukh NS. Safety assessment of McB-E60 (extract of a Momordica sp.): subchronic toxicity study in rats. Toxicol Rep. 2016;3:481-9.

53. Xu X, Shan B, Liao CH, Xie JH, Wen PW, Shi JY. Anti-diabetic properties of Momordica charantia L. polysaccharide in alloxan-induced diabetic mice. Int J Biol Macromol. 2015:81:538-43.

54. Karan SK, Mondal A, Mishra SK, Pal D, Rout KK. Antidiabetic effect of Streblus asper in streptozotocin-induced diabetic rats. Pharm Biol. 2013:51(3):369-75.

55. Zahra K, Malik MA, Mughal MS, Arshad M, Sohail MI. Hepatoprotective role of extracts of Momordica Charantia L. in acetaminophen-induced toxicity in rabbits. J Anim Plant Sci. 2012;22(2):273-7.
56. Verissimo LF, Bacchi AD, Zaminelli T, de Paula GHO, Moreira EG. Herbs of interest to the Brazilian Federal Government: female reproductive and developmental toxicity studies. Rev Bras Farmacogn. 2011;21(6):1163-71.

57. Uche-Nwachi EO, McEwen C. Teratogenic effect of the water extract of bitter gourd (Momordica charantia) on the Sprague Dawley rats. Afr J Tradit Complement Altern Med. 2009;7(1):24-33.

58. Sheffield JS, Siegel D, Mirochnick M, Heine RP, Nguyen C, Bergman KL, Savic RM, Long J, Dooley KE, Nesin M. Designing drug trials: considerations for pregnant women. Clin Infect Dis. 2014;59(Suppl 7):S437-44.

59. Sekar DS, Sivagnanam K, Subramanian S. Antidiabetic activity of Momordica charantia seeds on streptozotocin induced diabetic rats. Die Pharmazie. 2005;60(5):383-7.

60. Ahmad Z, Zamhuri KF, Yaacob A, Siong CH, Selvarajah M, Ismail A, Nazrul Hakim M. In vitro anti-diabetic activities and chemical analysis of polypeptide-k and oil isolated from seeds of Momordica charantia (bitter gourd). Molecules. 2012;17(8):9631-40.

61. Teixido E, Piqué E, Boix N, Llobet J, Gomez J. Zebrafish as a model for developmental toxicity assessment; 2015. p. 65-83.

62. Sipes NS, Padilla S, Knudsen TB. Zebrafish-as an integrative model for twenty-first century toxicity testing. Birth Defects Res C. 2011;93(3):256-67.

63. Behl M, Hsieh JH, Shafer TJ, Mundy WR, Rice JR, Boyd WA, Freedman JH, Hunter ES, Jarema KA, Padilla S, et al. Use of alternative assays to identify and prioritize organophosphorus flame retardants for potential developmental and neurotoxicity. Neurotoxicol Teratol. 2015:52:181-93.

64. Zang LQ, Shimada Y, Nishimura N. Development of a novel zebrafish model for type 2 diabetes mellitus. Sci Rep. 2017:7:1461

65. Pereira J, Camara JS. Effectiveness of different solid-phase microextraction fibres for differentiation of selected Madeira island fruits based on their volatile metabolite profile--identification of novel compounds. Talanta. 2011; 83(3):899-906

66. Sena S, Rasmussen IR, Wende AR, McQueen AP, Theobald HA, Wilde N, Pereira RO, Litwin SE, Berger JP, Abel ED. Cardiac hypertrophy caused by peroxisome proliferator- activated receptor-gamma agonist treatment occurs independently of changes in myocardial insulin signaling. Endocrinology. 2007;148(12):6047-53.

67. Bakkers J. Zebrafish as a model to study cardiac development and human cardiac disease. Cardiovasc Res. 2011:91(2):279-88.

68. Stainier DY, Lee RK, Fishman MC. Cardiovascular development in the zebrafish. I. Myocardial fate map and heart tube formation. Development. 1993;119(1):31-40.

69. Dahme T, Katus HA, Rottbauer W. Fishing for the genetic basis of cardiovascular disease. Dis Model Mech. 2009:2(1-2):18-22.

70. Erden I, Ordu S, Erden EC, Caglar SO. A case of atrial fibrillation due to Momordica charantia (bitter melon). Ann Saudi Med. 2010;30(1):86-7.

71. Westerfield M. Zebrafish book: a guide for the laboratory use of zebrafish (Danio rerio). 5th ed. Eugene: University of Oregon Press; 2007.

72. Strahle U, Scholz S, Geisler R, Greiner P, Hollert H, Rastegar S, Schumacher A Selderslaghs I, Weiss C, Witters $\mathrm{H}$, et al. Zebrafish embryos as an alternative to animal experiments-a commentary on the definition of the onset of protected life stages in animal welfare regulations. Reprod Toxicol. 2012; 33(2):128-32.

73. Bartlett DH, Silk SB. Office of Laboratory Animal Welfare Comments. Zebrafish. 2016:13(6):563-4.

\section{Publisher's Note}

Springer Nature remains neutral with regard to jurisdictional claims in published maps and institutional affiliations.

Ready to submit your research? Choose BMC and benefit from:

- fast, convenient online submission

- thorough peer review by experienced researchers in your field

- rapid publication on acceptance

- support for research data, including large and complex data types

- gold Open Access which fosters wider collaboration and increased citations

- maximum visibility for your research: over $100 \mathrm{M}$ website views per year

At BMC, research is always in progress.

Learn more biomedcentral.com/submission 